\title{
Forensic Presentations of Malignant Lymphoma in Nigeria
}

\author{
Wilson I B Onuigbo* \\ Department of Pathology, Medical Foundation \& Clinic, Nigeria
}

*Corresponding author: Wilson I B Onuigbo, Department of Pathology, Medical Foundation \& Clinic, 8 Nsukka Lane, Enugu-410000, Nigeria

Submission: 想 December 06, 2017; Published: 監January 25, 2018

\begin{abstract}
Long ago, it was the author's privilege to contribute a 5-paged historical account on Hodgkin. Recently, my contribution concerned also a medicolegal case reported by that great man. Therefore, it was of interest to come across in my home country, Nigeria, recent reports on lymphoma. Accordingly, let me contribute two medico-legal examples from my own people, the Igbos or Ibos. Both specimens happened to have been submitted to me at a Regional Pathology Laboratory which I headed personally, the senders being missionary doctors working in a hinterland hospital. What necessarily follows is the establishment of an effective oncology policy with the active collaboration of voluntary agencies.
\end{abstract}

Keywords: Hodgkin; Disease; History; Missionaries; Hinterland; Afikpo; Igbos; Nigeria

\section{Introduction}

In 1964, the author was privileged to contribute to Medical History a 5-paged Biography of the eponymous Thomas Hodgkin (1798-1866) Onuigbo WIB [1]. Recently [2], he has added the intriguing medico-legal case reported by that great man himself way back in 1832. Therefore, it is deemed worthy of reportage that two Missionary doctors working among the Igbos or Ibos, a Nigerian ethnic group [3], submitted to him two priceless postmortem specimens that proved to be lymphomas. Incidentally, this is in keeping with the Birmingham (UK) group's suggestion that the establishment of a histopathology data pool facilitates epidemiological analysis [4]. Moreover, much as there was debate in UK as to whether distant hospitals could benefit from service rendered from a central institution [5], these local examples are not those of dubiety but of propriety!

\section{Investigation}

The local practice was established personally as the pioneer pathologist heading the Eastern Nigerian Pathology Laboratory situated at Enugu, the erstwhile Capital City. I encouraged practitioners to send to me formalin-fixed specimens with the proviso of providing adequate clinical notes. The two examples may be abridged thus:

\section{Case Reports}

1. AE, a female of 9 years of age, attended the Mater Hospital, Afikpo, to consult Dr Powell on 4th June, 1974. The illness was said to have been worrisome for one week. Later, the patient died at home, but the family wished to find out the cause of death. Chest
X-Ray showed no opacities. The liver was intact. Tumor tissue invaded the stomach and intestines. Therefore, retroperitoneal sarcoma was the provisional diagnosis.

On microscopy, the partly autolyzed tissues were sufficient enough for the diagnosis of widely invasive malignant lymphoma.

2. AU, a male of 22 years of age, attended the Mater Hospital, Afikpo, under Dr. Craenen on 1st May, 1975 Onuigbo WIB [6]. He had been sick for 1 month. On admission, there was a big swelling in the left parotid gland, and a smaller one on the right side. Generalised lymph node swellings were noted. No swelling was found in the liver or spleen. There was intermitted fever. Antibiotic treatment was of no avail. Post-mortem examination was suggested by the family. The clinical diagnosis was systemic fungal infection or Hodgkin.

At microscopy of the submitted liver, skin, parotid gland, and lymph nodes, I wrote: "The picture is that of malignant lymphoma affecting skin, parotid gland and some lymph nodes. Schstosomiasis is noted in the liver. I wish that you had sent more organs!"

\section{Discussion}

Apart from the main issue of malignant lymphoma, it is of note that schistosomiasis was present. Incidentally, the specimens received from the Afikpo region led to reports on this parasite elsewhere [6-8] and to the conclusion that this is an endemic area of schistosomiasis of the Haematobium species.

Turning to lymphoma proper, it is also of interest that work in the Western Region of Nigeria has centered on its specialized 
aspects such as regards immunochemical characterization [9] and orofacial manifestations [10]. The latest led to the plea that "The need for the establishment of an effective oncology policy with the active collaboration of voluntary agencies is emphasized." Clearly, this should be possible, seeing that the present work was based on materials submitted from a hinterland Missionary Hospital.

\section{References}

1. Onuigbo WIB (1964) Thomas Hodgkin (1798-1866) on cancer cell carriage. Medical History 11: 406-411.

2. Onuigbo WIB (2016) The medico-legal case reported by Hodgkin in 1832. Glob J Nurs Forens Stud 1(2): 1000102.

3. Basden GT (1966) Niger Ibos. Cass, London.

4. Macartney JC, Rollaston TP, Codling BW (1980) Use of a histopathology data pool for epidemiological analysis. J Clin Pathol 33(4): 351-353.
5. Lilleyman J (2002) From the President. Bull Roy Coll Pathol 117: 2-3.

6. Onuigbo WIB (1975) Schistosomiasis in the Igbos of Nigeria. Bull Sinai Hosp Detroit 23: 113-114.

7. Onuigbo WIB, Twomey D (1978) Schistosomiasis of ovarian thecoma. Med J Zamb 12: 27-28.

8. Onuigbo WIB, Anyaeze CM, Ozumba BC (1999) Sexual abuse simulated by schistosomiasis. Child Abuse Negl 23(9): 947-949.

9. Onwubuya IM, Adelusola KA, Durosinmi MA, Sabageh D, Ezike KN (2015) Lymphomas in Ile-Ife, Nigeria: Immunohistochemical characterization and detection of Epstein-Barr virus encoded RNA. J Clin Diagn Res 9(6): EC14-EC19.

10. Ugboko VI, Oginni FO, Adelusola KA, Durosinmi MA (2004) Orofacial non-Hodgkin's lymphoma in Nigerians. J Oral Maxill Surg 62(11): 13471350. 